\title{
Behaviour And Strength Of High Strength Concrete L-Beams Under Combined Shear, Bending And Torsional Loading
}

\author{
Omer Qarani Aziz \\ Assist Professor \\ Civil Eng. Department, \\ College of Engineering \\ University of Salahaddin
}

\author{
Ferhad R. Karim \\ Assist Lecturer \\ Building \& Construction \\ Department, \\ College of Engineering \\ University of Sulaimani
}

\begin{abstract}
This investigation examines experimentally the behavior and ultimate strength of L-shaped reinforced high strength concrete beams under combined shear, bending and torsion.

The experimental program consists of casting and testing (13) high strength concrete beams under bending, shear and torsion. The main parameters are the effect of compressive strength, the eccentricity and transverse to longitudinal reinforcement ratio.

An increase in transverse to longitudinal reinforcement ratio by $(21.43 \%)$ for beams under $80 \mathrm{~mm}$ eccentricity of loading causes decrease in ultimate resisting torsional moment by (13.19\%), and for an eccentricity of $170 \mathrm{~mm}$; the decrease in resisting torsional moment is (15.14\%). Increasing in eccentricity for torsion of $(112.5 \%)$ caused a decrease in load carry capacity by $(43.33 \%)$ if all types of reinforcement remain the same.

By using multiple nonlinear stepwise regression analysis, based on data in this research and from other literatures; equations are proposed for predicting shear strength at cracking and ultimate loads and torsional capacity at cracking and ultimate loads. These proposed equations showed good agreement when compared with equations given by Codes of practice like (ACI, Canadian and BS) and showed good relations..
\end{abstract}


Keywords: Bending, high strength concrete, L-shaped beams, shear, torsion.

\section{استخدام الاسفلت السائل لتحسين التربة الجبسية}

مهندس ماجستير مامعة تكريت

الخلاصة

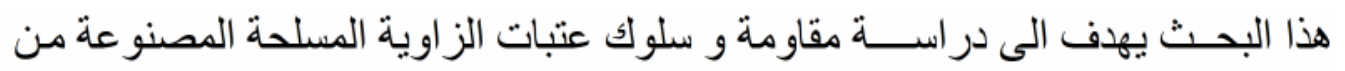

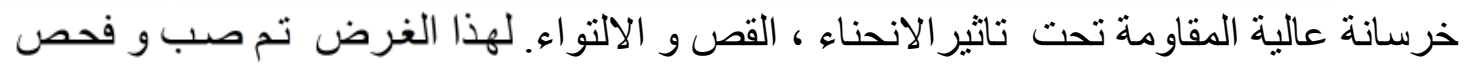

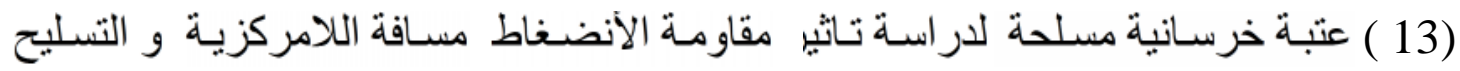

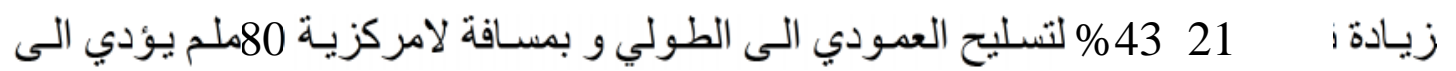

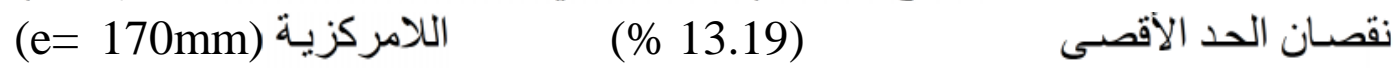

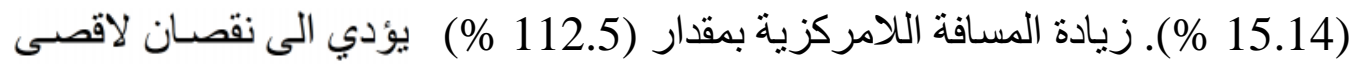
(43.33)

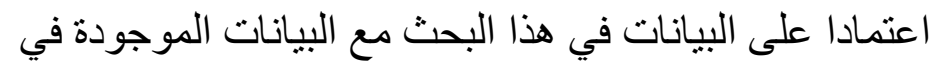

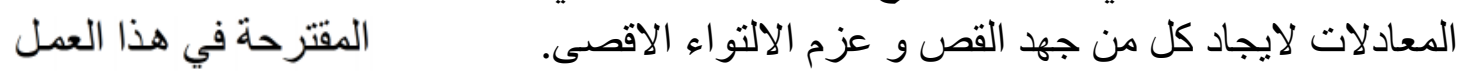

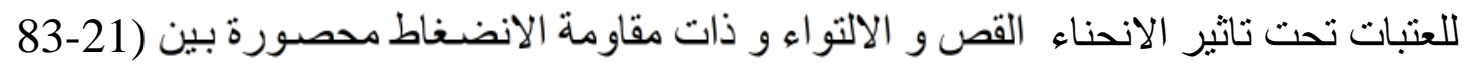

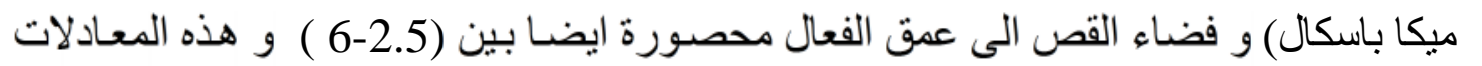

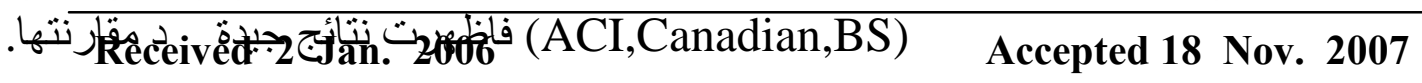

\section{Introduction:}


ACI committee $363^{(1)}$ defined high strength concrete (HSC) as a concrete having cylinder compressive strength exceeding $41 \mathrm{MPa}$ and it excludes concrete made using exotic materials or exotic techniques.

Generally, reinforced concrete members may be subjected to bending, shear and torsion sometimes with combination of others. Torsion on structural systems may be classified into two types ${ }^{(2)}$ :

1. Statically determinate torsion, in which the torsion can be determined from static alone.

2. Statically indeterminate torsion, in which the torsion cannot be determined from static alone and the twist is required for deformational compatibility between interconnecting elements.

The present investigation studies the strength and behavior of high strength concrete L-shaped beam. These beams are subjected to the combined actions of bending, shear with or without torsion.

\section{High Strength Concrete (HSC) beams subjected to torsion:}

Rasmussen and Baker ${ }^{(3)}$ (1995) studied the behavior of reinforced normal and high strength concrete beams subjected to pure torsion. For this purpose they cast twelve rectangular beams, three of them are NSC and the other HSC, taking the compressive strength as a variable only. They concluded the followings: -

1. Cracking of a HSC beam was more brittle than that for a NSC beam.

2. The number of cracks at failure in HSC and NSC beams is approximately the same, whereas the maximum crack width at failure increases as the concrete strength increases.

3. Total twist angle at failure of NSC and HSC beams are the same, and

4. Modulus of elasticity and torsional stiffness for HSC are higher than that of NSC.

Rasmusien and Baker ${ }^{(4)}$ (1995) proposed a theory and a design equation for predicting torsion in reinforced normal and high strength concrete beams with rectangular shapes. In their investigation they 
examined the behavior of reinforced HSC beams failing in pure torsion compared to 159 NSC beams. The followings were concluded: -

1- The peak strain for HSC is influenced by type, shape and size of aggregate, and they suggested an equation for predicting strain (CEBModel) based on the experimental test data).

2- The determination of the torsional capacity of reinforced concrete beams using the theory described by Collins and Mitchell ${ }^{(5)}$ based on the stress block factors $(\beta, \alpha)$ for compressive strength up to $110 \mathrm{MPa}$ (modified stress block factors SBF). With concrete strain of 0.003 , the stress block factors $\left(\alpha^{*} \beta\right)$ lead to a good description of the capacity. The study of stress block factor shows that:

1. The ACI-Code recommendations seem applicable for both NSC and HSC.

2. A modification of the shear block factor calculation used on the space truss model has therefore been suggested; in line with ACI approach. It was also shown that cover must be ignored in calculating torsional capacity.

3. The Canadian code recommendations were also conservative for NSC but slightly unsafe in the HSC range.

Koutchaukali and Belarbi ${ }^{(6)}$ (2001) studied the torsional strength of high strength concrete beams. For this purpose, they cast and tested nine full size rectangular beams under pure torsion; the main parameters were compressive strength of concrete and longitudinal reinforcement ratio.

They concluded the followings: -

1. The torsional capacity of under-reinforced beams is independent of concrete strength.

2. The amount of longitudinal reinforcement was effective in controlling crack width than the amount of transverse reinforcement.

3. Minimum amount of reinforcement defined by ACI Committee ${ }^{(7)}$ is inadequate for equilibrium torsion of high strength reinforced concrete beams. 


\section{Reinforced Concrete beams subjected to combined bending and torsion:}

Zararis and Penelis ${ }^{(8)}$ (1986) studied reinforced concrete T-beams in torsion and bending, taking into account the effect of reinforced flanges on the torsion capacity of reinforced concrete T-beams.

They predicted the following equations:

Case 1: - when the upper reinforcement yields.

$$
\left(\frac{T_{u}}{T_{u \circ}}\right)^{2}=1+1.023\left(\frac{M_{u}}{M_{u \circ}}\right)
$$

Case 2: - When the lower reinforcement yields.

$$
\left(\frac{T_{u}}{T_{u \circ}}\right)^{2}=2.45\left(1-\frac{M_{u}}{M_{u \circ}}\right)
$$

The following points are concluded:

1. Two failure mechanisms were identified for T-beams, as well as for rectangular beams, subjected to combined torsion and bending. First mechanism corresponds to full cracking of the beam and occurs when torsion prevails. While the second mechanism corresponds to partial cracking of the beam and occurs when bending prevails.

2. The reinforced flanges contribution to the torsion capacity of the Tbeam is significant, especially when torsion prevails.

3. Experimental results show that for T-beams with reinforced flanges there is an effective overhanging flange width in torsion greater than three times the flange thickness.

4. Special consideration should be given to T-beams with un reinforced flanges, where the ultimate strength should be limited to the web strength only.

Leung and Schnobrich ${ }^{(9)}$ (1987) studied reinforced concrete beams subjected to bending and torsion, the diagonal compression field theory was extended to study the post cracking behavior of reinforced concrete 
sections subjected to combined axial force, biaxial bending and torsion. The theory assumes that when concrete cracks are formed by the torsion, the reinforced concrete member becomes a hollow section with varied wall thickness, which is then discretized into a wall element system. The torsion applied to the section is resisted by the stresses in the compression concrete members, which spiral around the beam at an angle of 45degree. This method of modeling is named diagonal compression field theory. They concluded the following points: -

1. A diagonal compression field model is extended to combine loading and general cross section forms.

2. The model assumes that the section subjected to combined loading including torsion becomes a hollow section as a consequence of cracking. Thus the section is modeled as a wall element system.

3. The proposed model can be used to predict experimental results for combined bending and torsion of both rectangular and slab sections.

4. The proposed theory neglects the tensile strength of concrete, which in fact may be up to (10\%) of compressive strength and therefore can not be ignored in some instances.

5. The concept of concrete softening should improve significantly the prediction by the compressive field theory.

\section{Reinforced Concrete beams subjected to combined bending and shear:}

Ahmad and Lue ${ }^{(10)}$ (1987) studied flexural -shear interaction of reinforced HSC beams, for this purpose they have taken fifty -four reinforced concrete beams using HSC which have $f c^{\prime}>41.37 \mathrm{MPa}$ and tested under monotonically increasing loads to determine the effect of shear on the flexural resistance capacity and failure mode. All the beams were designed as singly reinforced rectangular members without shear reinforcement. The variable parameters are shear span to effective depth 
ratio $(\mathrm{a} / \mathrm{d})$ and longitudinal reinforcement for bending $\rho_{w}$. They proposed flexural-shear interaction model as follows: -

$$
\left.\frac{M_{f}}{M_{f l}}=\frac{1}{k}\left(\frac{d}{a}\right)^{n} \quad \text { for } \frac{a}{d}<\frac{a}{d}\right)_{t r p}
$$

$$
\left.\frac{M f}{M f l}=\frac{1}{F B A}\left(\frac{a}{d}\right) \quad \text { for } \frac{a}{d}>\frac{a}{d}\right)_{t r p}
$$

Where;

$\left.\frac{a}{d}\right)_{t r p}:$ Refers to the shear span to depth ratio at which the ratio $\frac{M_{f}}{M_{f l}}$ is minimum, $=10\left[\frac{\log (F B A / k)}{(n+1)}\right]$

$M_{f}:$ Ultimate moment with shear, kN.m.

$M_{f l}:$ Moment of resistance without shear, kN.m.

$k$ : Coefficient used to account for the influence of biaxial stress conditions on behavior of concrete in arch zone. the value of $\mathrm{k}=0.9$

$n:$ Is a calibrating factor

$F B A$ : Flexural beam action, $\mathrm{MPa}$

$$
F B A=\rho_{w} \cdot f_{y}\left\{1-\left[\left(\rho_{w} \cdot f_{y}\right) /\left(1.7 f_{c}\right)\right]\left[3.282291 *\left(f_{c^{\prime}}\right)^{0.5}\right]\right\}
$$

They illustrated the following points:-

1. The results indicate that shear reduces the flexural resistance of the beams.

2. The results suggest that the relative flexural strength of HSC beams is inversely proportional to steel ratio and directly proportional to $f_{c}$, for $\rho_{w}<1.88 \%$. 
3. Empirical equations were developed to reflect the reduction in flexural strength of reinforced concrete beams due to influence of shear.

Roller and Russell ${ }^{(11)}$ (1990) studied shear strength of HSC beams with web reinforcement, for this purpose they have cast ten reinforced concrete beams. All the beams were designed in accordance with the provision of ACI-318-83.The parameters taken as variables are: Compressive strength ranging between (69-124) $\mathrm{MPa}$, and web reinforcement ranging between minimum to maximum according to ACICode. The results indicate that for non-prestressed HSC members subject to shear and flexural only, the minimum quantity of shear reinforcement specified in ACI 318-83 needs to be increased as the $f_{c}$,increases.

\section{Reinforced Concrete beams subjected to combined shear and torsion:}

Rahal, and Collins ${ }^{(12)}$ (1995) studied the analysis of sections subjected to combined shear and torsion. For this purpose a three dimensional behavior truss model capable of analyzing rectangular reinforced and prestressed concrete sections subjected to combined loading is presented. This model use the principles of the modified compression field theory (MCFT), and is capable of analyzing sections subjected to combined biaxial bending, biaxial shear, torsion and axial load. The model provides a check on spalling of the concrete cover for sections subjected to combined shear and torsion.

\section{Reinforced Concrete beams subjected to combined bending, shear \& torsion:}

Rajagopalan, K.S. ${ }^{(13)}$ (1980) studied combined torsion, bending and shear on L-beams. In the research fifteen long beams subjected to combined loading are taken, which is represented as an eccentric single load act at center of span. The objectives of his study were:

1. The effect of torsion on the steel stress in the main longitudinal bars.

2. Checking Behera's interaction equation, used for beams having $\mathrm{h} / \mathrm{bw}$ equal to 2 . 
He proposed the following equations:

$$
\begin{aligned}
& \left(\frac{T_{u}}{0.5 \cdot T_{0}}\right)^{2}+\left(\frac{V_{m}}{V_{\circ}}\right)^{2}=1 \\
& \left(\frac{T_{u}}{T_{0}}\right)^{2}+\left(\frac{V_{u}}{V_{0}}\right)^{2}=1
\end{aligned}
$$

Where:

$$
\begin{aligned}
& V_{u}: \text { Nominal ultimate shear stress } \\
& V_{0}: \text { Shear capacity of the section, equal to }\left(0.17 \sqrt{f_{c}}+r \cdot f_{y s}\right) \\
& V_{m}: \text { Shear strength of the member corresponding to the moment } \\
& \text { capacity of the section } \\
& T_{0}: \text { Torsion strength of the section under pure torsion. } \\
& T_{u}: \text { Ultimate torque at a section. } \\
& \text { r: transverse reinforcement ratio for shear. }
\end{aligned}
$$

He concluded the following points:

1. Behera's interaction surface adequately predicts the ultimate strengths of beams under torsion combined with flexural and shear.

2. The stresses at diagonal cracking are smaller in beams with $h / b_{w}=3$ compared to those with $\mathrm{h} / \mathrm{b}_{\mathrm{w}}=2$.

3. The presence of torsion induces additional tension in the $\rho_{\mathrm{w}}$. This excess tension generally varies in the same way as the twist angle. This excess steel stress corresponding to any twist angle seems independent of the stirrups.

\section{Experimental Program:}

\section{Detail of the specimens:}

All the tested specimens have the dimensions of about $\left(b_{w}=220 \mathrm{~mm}\right.$, $\mathrm{b}_{\mathrm{f}}=320 \mathrm{~mm}, \mathrm{~h}=300 \mathrm{~mm}, \mathrm{hf}=110 \mathrm{~mm}$ and $\mathrm{L}=2200 \mathrm{~mm}$ ), these dimensions 
are identifiable with ACI Code (ACI 318R-99) section 8-10 as shown in Fig. (1a). Different methods for distribution of the longitudinal steel bars can be observed in two layers in shear span only as shown in Fig. (1b).The tested specimens were divided into three groups [C, D and E] as given in Table (1). All the beams were designed to fail in torsion, and the variables in each group are transverse to longitudinal reinforcement ratio for torsion $\left(\rho_{\mathrm{t}} / \rho_{\mathrm{L}}\right)$ which ranged between [0and 6.8], the compressive strength of concrete ranged from $30 \mathrm{MPa}$ to $70 \mathrm{MPa}$ and the eccentricity of loading on beams which ranged from $80 \mathrm{~mm}$ to $170 \mathrm{~mm}$.

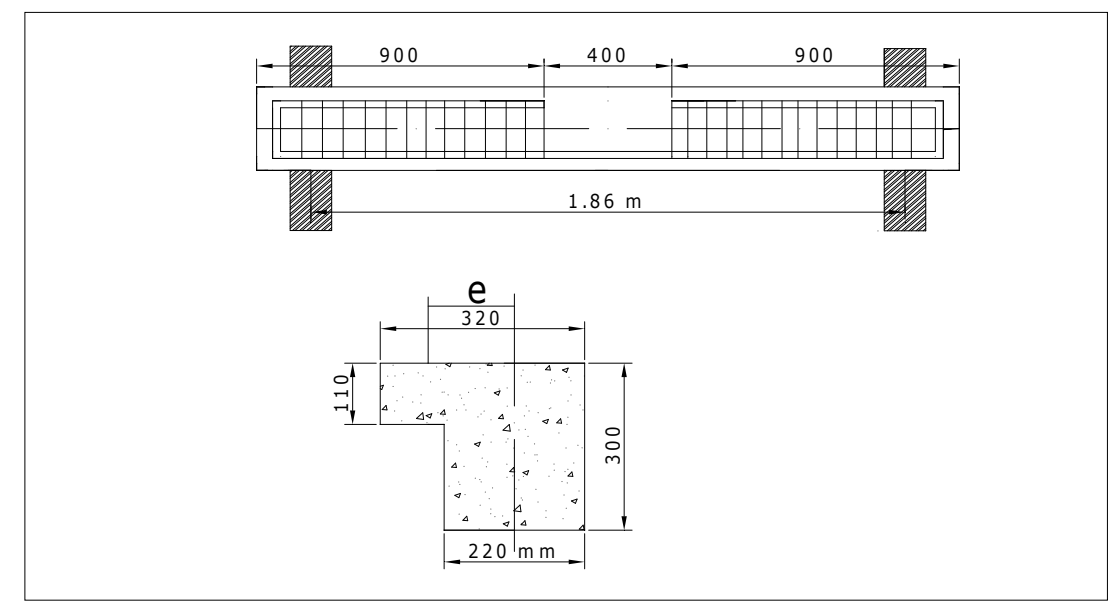

a. Layout and cross section dimensions (Dimensions in $\mathbf{m m}$ ) 


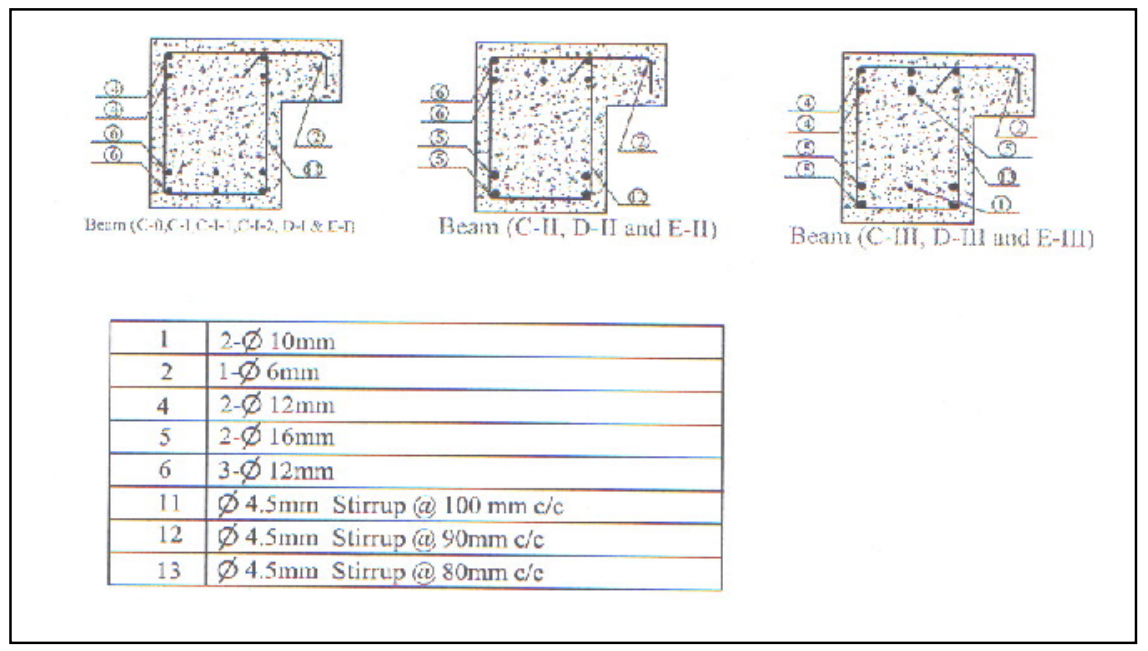

b. Details of reinforcement for the tested specimens

Fig. 1 Details of the tested specimens

\section{Mix proportion:}

In the present investigation the initial proportions were based on those attained by Aziz ${ }^{(14)}$ and Buni ${ }^{(15)}$ and the following steps were followed: -

A .The fine and coarse aggregate were sieved, washed and air dried.

B. Slump tests were made on different mixes having different amounts of cement content to give slump between $(5-100 \mathrm{~mm})$. 
C. Trial mixes were made, the aggregate to cement ratio ranged between (2.6-4.89). The following equation can be solved for the total aggregate weight, knowing the weight of cement, water and the bulk specific gravity of the materials:

$$
\left(\frac{W_{w}}{\gamma_{w}}\right)+\left(\frac{W_{c}}{\gamma_{c}}\right)+\left(\frac{W_{s}}{\gamma_{s}}\right)+\left(\frac{W_{g}}{\gamma_{g}}\right)+\left(\frac{W_{A d}}{\gamma_{A d}}\right)=1
$$

Where $\mathrm{W}_{\mathrm{w}}, \mathrm{W}_{\mathrm{c}}, \mathrm{W}_{\mathrm{s}}, \mathrm{W}_{\mathrm{g}} \& \mathrm{~W}_{\mathrm{Ad}}$ are weight of water, cement, sand, gravel and admixture respectively and $\gamma_{\mathrm{w}}, \gamma_{\mathrm{c}}, \gamma_{\mathrm{s}}, \gamma_{\mathrm{g}}$ and $\gamma_{A d}$ : are the bulk specific gravity of water, cement, sand, gravel and admixture respectively.

D. For each concrete mix six cylinders $(150 \times 300 \mathrm{~mm})$ were cast; three of them tested at age of 7 days and the other at age of 28 days.

E. Some of mixing process for the trial mixes was done by means of hand.

F. Then the mix proportions of beams selected to obtain different compressive strength as shown in Table (2).

Table (1) Details of the specimens

\begin{tabular}{|c|c|c|c|c|c|c|c|c|c|c|}
\hline $\begin{array}{l}\text { Beam } \\
\text { No. }\end{array}$ & $\begin{array}{l}\mathrm{b}_{\mathrm{w}^{-}} \\
\mathrm{mm}\end{array}$ & $\begin{array}{l}\mathrm{d}- \\
\mathrm{mm}\end{array}$ & $\begin{array}{l}\rho_{\mathrm{w}-\%} \\
\text { at } \\
+\mathrm{ve} \\
\text { M.S. } \\
\text { and at } \\
\text {-ve } \\
\text { M.S }\end{array}$ & $\begin{array}{l}\rho_{\mathrm{L}-\%} \\
\text { total }\end{array}$ & $\rho_{\mathrm{t}-\%}$ & $\begin{array}{l}\mathrm{fc}^{\prime}- \\
\mathrm{MPa}\end{array}$ & $\begin{array}{l}\rho_{\mathrm{t}} / \rho_{\mathrm{L}} \\
\%\end{array}$ & $\begin{array}{l}\rho_{\mathrm{v}} \text { fvy } \\
\mathrm{MPa}\end{array}$ & $\begin{array}{l}\mathrm{e} \\
\mathrm{mm}\end{array}$ & $\begin{array}{l}\text { design } \\
\text { load } \\
\mathrm{P}_{\text {theo.- }} \\
\mathrm{kN}^{* *}\end{array}$ \\
\hline $\mathrm{C}-\mathrm{O}^{+}$ & 223 & 250 & Min. & 1.03 & 0.07 & 43.38 & 6.8 & 0.333 & 80 & 136.7 \\
\hline $\mathrm{C}-\mathrm{I}^{+}$ & 222 & 251 & Min. & 1.03 & 0.07 & 59.20 & 6.8 & 0.333 & 80 & 136.7 \\
\hline $\begin{array}{l}\text { C-I- } \\
1^{+}\end{array}$ & 221 & 246 & Min. & 1.03 & 0.07 & 35.50 & 6.8 & 0.333 & 80 & 136.7 \\
\hline $\begin{array}{l}\text { C-I- } \\
2^{+}\end{array}$ & 223 & 249 & Min. & 1.03 & 0.07 & 75.22 & 6.8 & 0.333 & 80 & 136.7 \\
\hline $\begin{array}{l}\text { C-I- } \\
3^{+}\end{array}$ & 223 & 248 & Min. & 1.03 & 0.00 & 62.88 & 0.0 & 0.000 & 80 & 79.22 \\
\hline $\mathrm{D}^{-\mathrm{I}^{+}}$ & 224 & 252 & Min. & 1.03 & 0.07 & 64.51 & 6.8 & 0.333 & 120 & 91.1 \\
\hline
\end{tabular}




\begin{tabular}{|l|l|l|l|l|l|l|l|l|l|l|}
\hline E-I $^{+}$ & 222 & 253 & Min. & 1.03 & 0.07 & 68.42 & 6.8 & 0.333 & 170 & 64.3 \\
\hline C-II $^{+}$ & 223 & 248 & Min. & 1.57 & 0.09 & 71.14 & 5.7 & 0.333 & 80 & 152.1 \\
\hline D-II $^{+}$ & 222 & 250 & Min. & 1.57 & 0.09 & 59.33 & 5.7 & 0.333 & 120 & 101.4 \\
\hline E-II $^{+}$ & 223 & 247 & Min. & 1.57 & 0.09 & 66 & 5.7 & 0.333 & 170 & 71.6 \\
\hline $\begin{array}{l}\text { C- } \\
\text { III }^{+}\end{array}$ & 222 & 250 & Min. & 1.96 & 0.11 & 56.18 & 5.6 & 0.333 & 80 & 171.3 \\
\hline $\begin{array}{l}\text { D- } \\
\text { III }^{+}\end{array}$ & 223 & 249 & Min. & 1.96 & 0.11 & 61.72 & 5.6 & 0.333 & 120 & 114.2 \\
\hline E-III $^{+}$ & 223 & 246 & Min. & 1.96 & 0.11 & 60.49 & 5.6 & 0.333 & 170 & 80.6 \\
\hline
\end{tabular}

+: Beams under bending, shear and torsion **: according to ACI Code

Table (2) Mix proportions of beams

\begin{tabular}{|l|l|}
\hline \multirow{2}{*}{ Beam No. } & Mix proportions \\
\cline { 2 - 3 } & Ad: W: C: $:$ G \\
\hline C-0 & $0: 0.44: 1: 0.91: 1.69$ \\
\hline C-I-1 & $0: 0.50: 1: 0.78: 1.82$ \\
\hline C-I-2 & $0.0035: 0.34: 1: 1.194: 1.854^{+}$ \\
\hline C-I-3 & $0: 0.33: 1: 1.194: 1.854$ \\
\hline Others & $0.0035: 0.32: 1: 1.175: 2$ \\
\hline
\end{tabular}

${ }^{+}:$Reviberated after initial setting

\section{Mixing method:}

The mixing procedure is important for obtaining the required workability. A $\left(0.08 \mathrm{~m}^{3}\right)$ tilting mixer was used. The interior surface of the mixer was cleaned and moistened before placing the materials; initially the coarse aggregate and fine aggregate were put in the mixer, followed by $25 \%$ of the mixing water with admixture to wet them. Then the cement was added, followed by $75 \%$ of the remaining water with admixture .The mixing operation continued until uniform mix obtained.

\section{Casting and curing:-}

Casting was started by placing the mixture inside the steel molds using a trowel, the mixture was placed in three layers and each layer was vibrated for about 20 seconds using internal vibrator. The top layer was vibrated until the number of bubbles appeared on the surface was reduced and finished with a steel trowel. After five hours the molds were covered with damp canvas cloth and left in the laboratory for about twelve hours. Then the specimens were taken out in molds and covered with the damp 
canvas for twenty -eight days after that left in air temperature and humidity until date of testing.

Testing of high strength concrete beams:

Properties of high strength concrete:

Slump test according to ASTM C143 ${ }^{(16)}$ was done on the fresh concrete while tests for compressive strength, splitting tensile strength, modulus of elasticity and Poisson's ratio were carried out on the hardened concrete.

\section{Compressive strength:}

The test procedures followed ASTM C39 ${ }^{(17)}$. Standard steel cylinders ( $150 \mathrm{~mm}$ in diameter by $300 \mathrm{~mm}$ height) were used, with casting of beams, three cylinders were cast, and each cylinder cast in two layers. The specimens were cured by immersing in saturated lime water for about 28-days then left at air moisture at a room temperature (20-29 $\left.C^{\circ}\right)$. The concrete cylinders were tested at age of 120-days except beams C-I1, C-I-2, and C-I-3 were tested at age of 28 days.

\section{Splitting tensile strength of concrete:}

The splitting tensile strength of concrete specimens was carried out according to ASTM C496 ${ }^{(18)}$.

\section{Static modulus of elasticity of concrete in compression:}

The determination of static modulus of elasticity followed ASTM C469 ${ }^{(19)}$.Cylinders of $150 \mathrm{~mm}$ in diameter and $300 \mathrm{~mm}$ in height were used. The cylinders were cast and cured in saturated lime-water as those of compressive and splitting tensile strength tests. This test method provides a stress to strain relationship for hardened concrete under compression $^{(19)}$.

\section{Deflection measurements:}

Vertical deflections were measured at the mid-span of the beams and under the point loads using a dial-gauge of (30) $\mathrm{mm}$ with a minimum reading of $(0.01) \mathrm{mm}$. 


\section{Testing procedure:}

The beams were prepared one day before testing; the beams were painted by white color prior to testing in order to view crack propagation. An eighty -tons hydraulic testing machine used for testing the beams and shaft steel beam was used; with a span between two point loads of $[40 \mathrm{~cm}]$ in order to transfer the applied point loads on the beam. Initially the zero load readings for the mechanical strain gauges as well as the dial gauges were recorded and recheck the zero load reading. At each load stage the concrete surface strains and the dial gauge readings were taken, indicating cracking on surface of concrete, deflection at center and point load then the testing continued until the beam showed a drop in loading with increasing deformation. The load was applied on the beams as indicated in ACI committee through the loading structure (Fig. 2 )

\section{Discussion of test results:}

- Effect of compressive strength [fe']:

When the longitudinal

reinforcement for bending, torsion and transverse reinforcement for shear and torsion in beams are constant and under the same

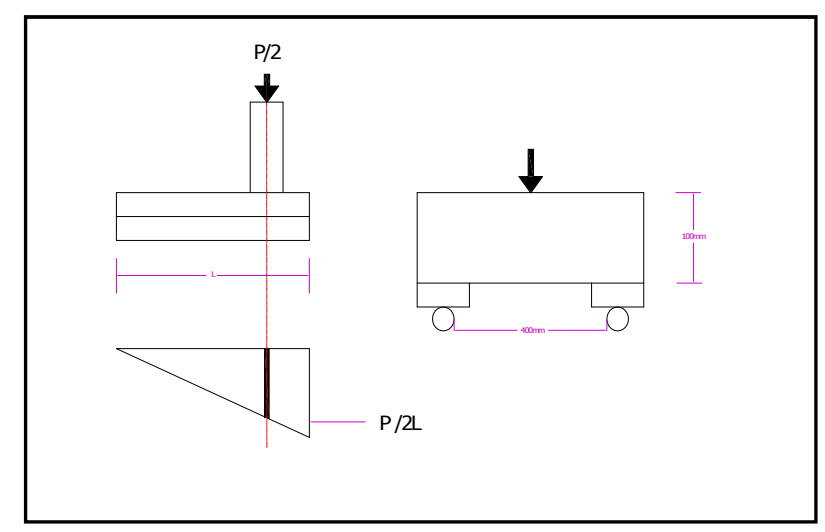
eccentricity, an increase in compressive strength by (111.9\%) has caused an increase in cracking shear strength and load carry capacity by about ( $131.26 \%$ and $22.9 \%$ ) respectively as given in Table(3).

structure of the tested

Fig. 2 Loading

\section{specimens}

Table (3) Results of the tested beams

\begin{tabular}{|c|c|c|c|c|c|}
\hline $\begin{array}{l}\text { Beam } \\
\text { No. }\end{array}$ & 岁 & $\mathrm{P}_{\mathrm{E}} / \mathrm{P}_{\mathrm{th}}$ & $\mathrm{P}_{\mathrm{E}}$ & Cracking load & Ultimate load \\
\hline
\end{tabular}




\begin{tabular}{|c|c|c|c|c|c|c|c|}
\hline & & & $\mathrm{kN}$ & & & & \\
\hline & & & & $\begin{array}{l}\text { Shear } \\
\mathrm{kN}\end{array}$ & $\begin{array}{l}\text { Torsio } \\
\mathrm{n} \\
\text { kN.m }\end{array}$ & $\begin{array}{l}\text { Shear } \\
\mathrm{kN}\end{array}$ & $\begin{array}{l}\text { Torsion } \\
\text { kN.m }\end{array}$ \\
\hline C-0 & III & 1.915 & 258 & 51.95 & $\begin{array}{l}2.482 \\
4\end{array}$ & 130.9 & 10.4 \\
\hline C-I & III & 2.134 & 288 & 91.93 & $\begin{array}{l}1.682 \\
5\end{array}$ & 145.9 & 11.6 \\
\hline C-I-1 & III & 1.814 & 248 & 41.9 & 2.05 & 125.9 & 9.97 \\
\hline C-I-2 & III & 2.223 & 304 & 96.9 & 2.45 & 153.9 & 12.27 \\
\hline C-1-3 & III & 2.650 & 210 & 61.9 & 2.45 & 106.9 & 8.45 \\
\hline D-I & III & 2.631 & 236 & 71.93 & $\begin{array}{l}2.483 \\
6\end{array}$ & 119.9 & 14.2 \\
\hline E-I & III & 2.686 & 169 & 71.93 & $\begin{array}{l}3.483 \\
7\end{array}$ & 86.4 & 14.5 \\
\hline C-II & III & 2.194 & 330 & 91.95 & $\begin{array}{l}1.682 \\
8\end{array}$ & 166.9 & 13.3 \\
\hline D-II & III & 2.562 & 256 & 71.93 & $\begin{array}{l}2.482 \\
3\end{array}$ & 129.9 & 15.4 \\
\hline E-II & III & 2.708 & 190 & 81.91 & $\begin{array}{l}3.479 \\
9\end{array}$ & 96.9 & 16.3 \\
\hline C-III & IV & 1.983 & 336 & 61.95 & $\begin{array}{l}1.683 \\
3\end{array}$ & 169.9 & 13.5 \\
\hline D-III & IV & 2.783 & 314 & 71.93 & $\begin{array}{l}2.482 \\
9\end{array}$ & 158.9 & 18.9 \\
\hline E-III & IV & 2.478 & 195 & 51.91 & $\begin{array}{l}4.330 \\
2\end{array}$ & 99.9 & 16.8 \\
\hline
\end{tabular}

III: torsional failure IV: flange failure 
$\mathrm{P}_{\mathrm{E}}$ : Experimental ultimate load $-\mathrm{kN} \quad \mathrm{P}_{\mathrm{th}}$ : Theoretical ultimate load-kN

\section{- Effect of eccentricity (e):}

For beams which have the same longitudinal reinforcement for torsion of $(1.02 \%)$ and the same amount of transverse reinforcement index for torsion of $(0.07 \%)$, when eccentricity is increased from $80 \mathrm{~mm}$ to $170 \mathrm{~mm}$, cause an increase in torsional resisting moment by about (21.53\%) after subtracting effect of compressive strength as shown in Fig.(3) . While an increase in torsional longitudinal reinforcement ratio from $1.02 \%$ to $1.96 \%$ and transverse reinforcement index from $0.07 \%$ to $0.11 \%$, and increase in eccentricity from $80 \mathrm{~mm}$ to $170 \mathrm{~mm}$ causes an increase in torsional resisting moment from $(21.53 \%)$ to $(24.47 \%)$ due to earlier yielding of reinforcement3).

\section{- Effect of longitudinal reinforcement of torsion $\rho_{\mathrm{L}}$ :}

For beams under load eccentric by $80 \mathrm{~mm}$ from centerline, an increase in longitudinal reinforcement for torsion by about (90.29\%) causes an increase in load carry capacity by about (11.17\%), while an increase in eccentricity from $80 \mathrm{~mm}$ to $170 \mathrm{~mm}$ cause a decrease in load carry capacity from $(11.17 \%)$ to $(7.34 \%)$ as shown in Fig.(4).

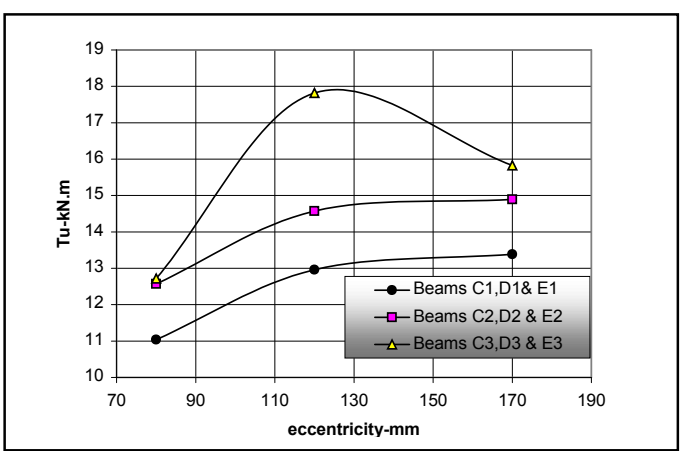

Figure (3) Torsional resisting moment versus eccentricity

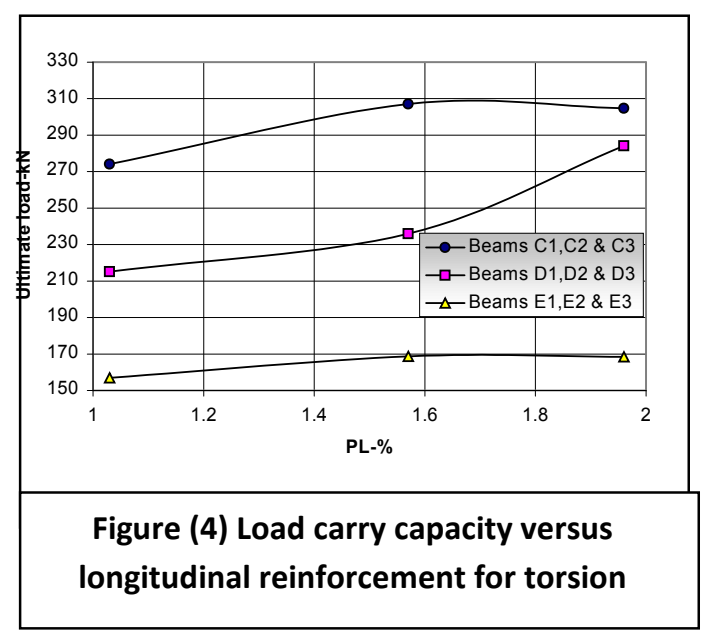


For beams under eccentricity of $80 \mathrm{~mm}$, an increase in transverse reinforcement index for torsion by $(66.34 \%)$ causes an increase in shear strength at ultimate load after subtracting the effect of compressive strength by $(27.3 \%)$.

- Effect of transverse to longitudinal reinforcement ratio $\left(\rho_{t} / \rho_{L}\right)$ :

For beams under eccentricity of $80 \mathrm{~mm}$, an increase in transverse to longitudinal reinforcement ratio for torsion by about $(21.43 \%)$ causes a decrease in ultimate resisting torsional moment by about (13.19\%), while an increase in eccentricity from 80 to $170 \mathrm{~mm}$ causes a decrease in resisting torsional moment from $(13.19 \%)$ to $(15.44 \%)$ as shown in Fig.(5).

Figure (5) Ultimate torsional moment versus

the transverse to longitudinal

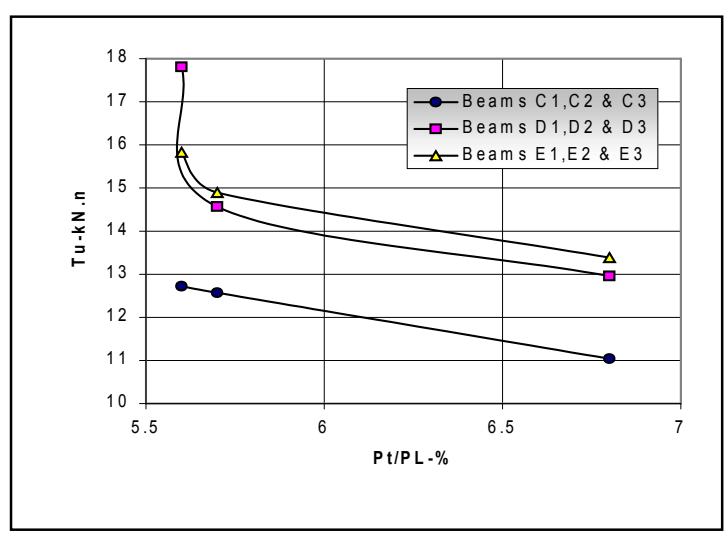

- Load and mid span deflection relationship:

Load versus deflection at mid span for beams under eccentric loads is shown in Fig. (6, 7, 8 and 9). The figures indicate that the deflection is increased at failure due to increasing in longitudinal reinforcement. The effect of both shear reinforcement and longitudinal reinforcement is negligible at a small percent of loading; beyond this load it becomes clear, curves are initiated in a linear form with constant slope at small percent of loading, and then rapidly changes to non-linear form with changing in the relation (slope). It can be seen from the Fig.(7), the values of deflection at ultimate load are greatest for beams with large amount of longitudinal reinforcement ratio if eccentricity is $80 \mathrm{~mm}$, but when eccentricity is increased, thus deflection decrease as shown in 
Fig.(9). Deflection has decreased for beams under torsion when longitudinal reinforcement increases.

\section{- Torsional moment-deflection relation:}

At the same torsional percent (i.e; $\mathrm{T} / \mathrm{Tu}$ ) and the same eccentricity, an increase in torsional longitudinal reinforcement causes the increase in deflection at mid span. While for beams under large applied torque effect of this reinforcement is reduced as shown in Fig.( 10, 11, and 12).

\section{- Torsional moment -angle of twist relation:}

The angle of twist for beams in groups $(\mathrm{C}, \mathrm{D} \& \mathrm{E})$ was measured over the point load location of the span. The torque -twist curve for group $\mathrm{C}, \mathrm{D}$ and $\mathrm{E}$ are shown in Figures $(13,14,15 \& 16)$. The shape of torquetwist curve for beams tested in high torsional moment can be described as a linear curve ascending from the origin until the cracking torque is reached. Beyond the cracking torque, a distinct reduction in the slope is apparent.

\section{- Crack patterns and modes of failure:}

In beams C-0,C-I,C-II,D-I,D-II,E-I and E-II Cracks may be observed in the shear span which has formed as a result of inclined tensile stress; the crack appears at the flange then extends to the bottom of the web. While with the increasing of load, crack at flange side extends spirally to the top at positive moment position then causing failure when this crack is connected between the location of the two point loads and the type of the crack is called helical crack. Typical crack patterns beams in-group C, D and E are shown in Fig. (17). The reference beam E2 failed in diagonal tension cracks (torsion) according to the following sequence:

\section{Flexure cracks formed at point loads.}

2. Shear flexure cracks formed at bottom in shear span for flange sides at first stage.

3. Cracks in previous step extend to bottom then other side later on.

4. Cracks at flange side [at positive moment position] extend to compressive zone in same side, then at the same time this crack extends to the support at the bottom side.

5. After the cracks extend to the compressive zone at mid span, the load causes failure.
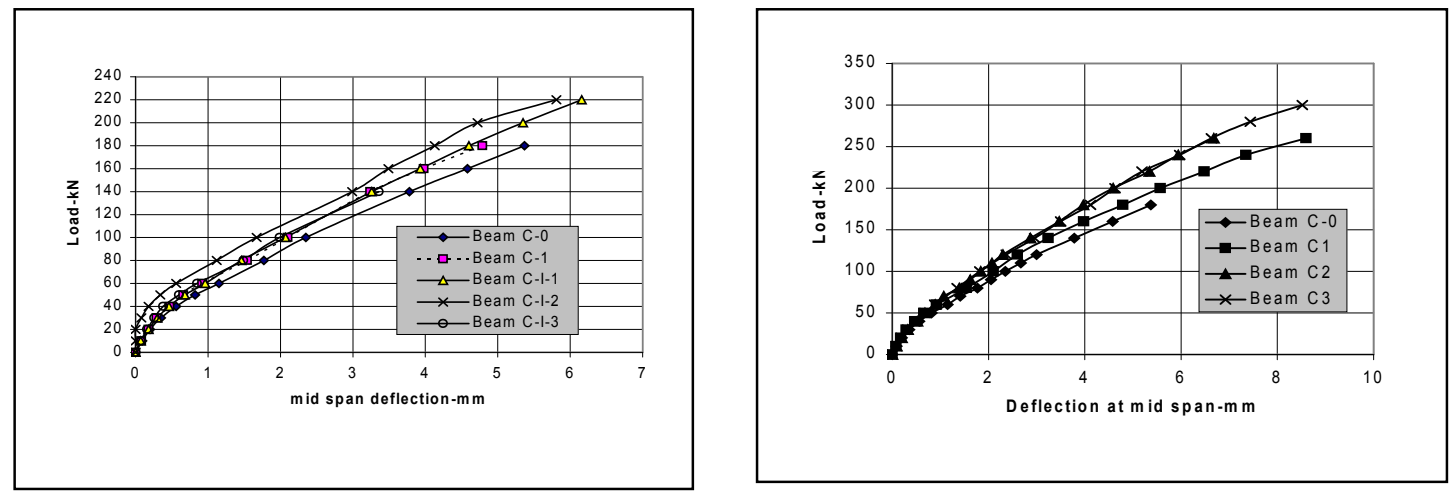
Figure (6) Load versus mid span deflection for beams

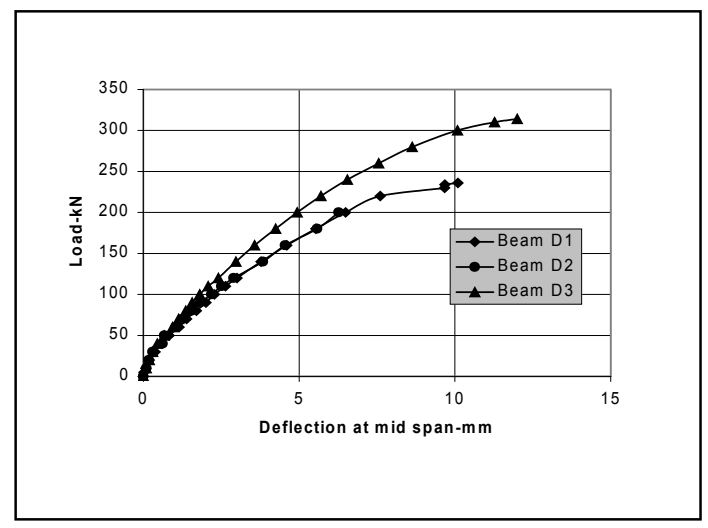

Figure (8) Load versus mid span

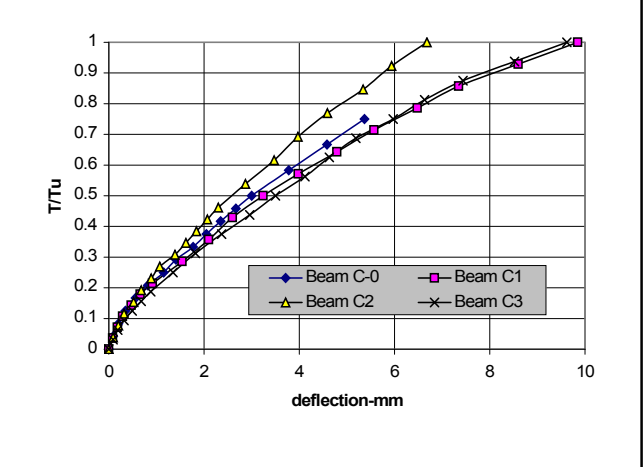

Figure (10) Torque versus deflection
Figure (7) Load versus mid span deflection (group C)

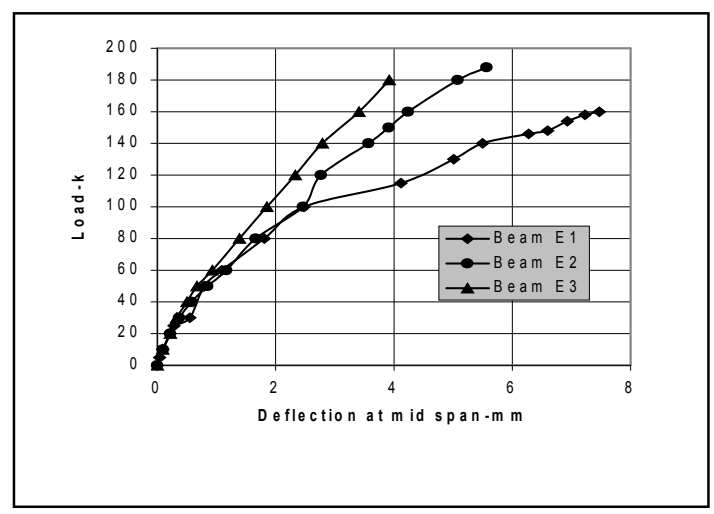

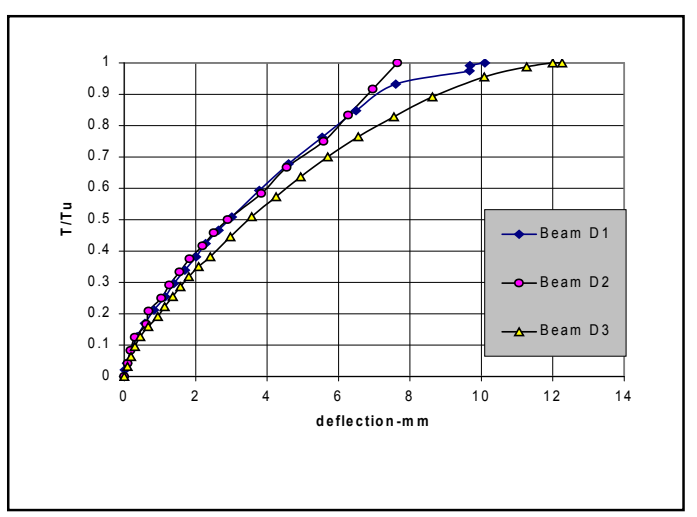


Figure (11) Torque versus deflection
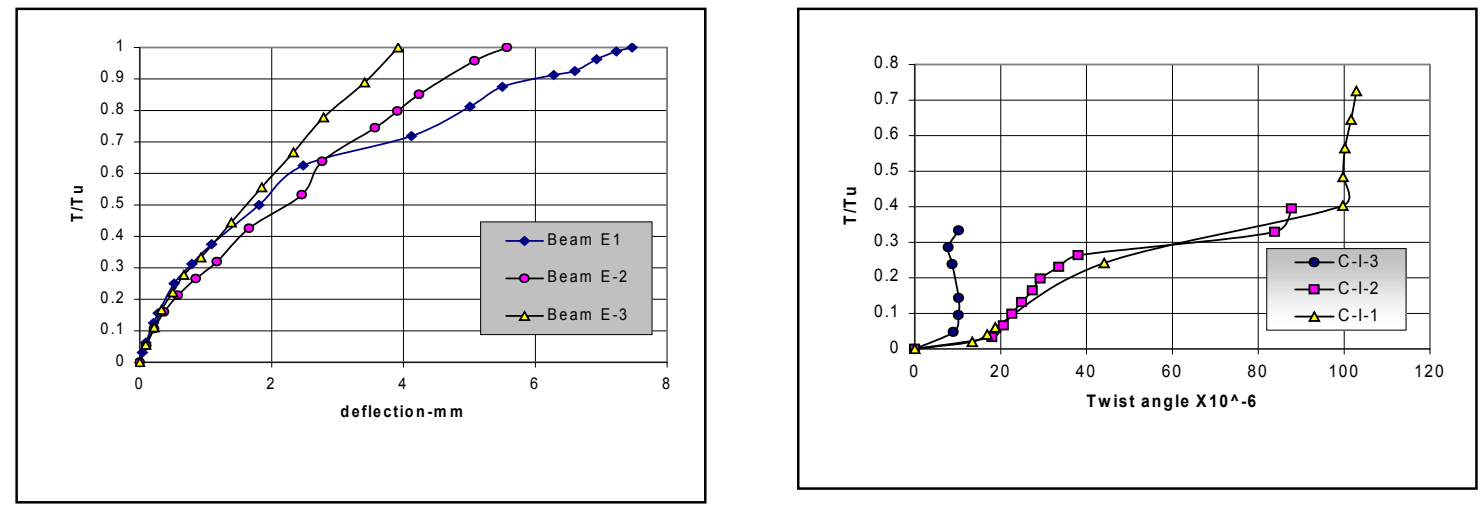

Figure (12) Torque versus deflection relation for beam in group $E$

Figure (13) Torsional moment versus angle of twist for beams in group $\mathrm{C}$
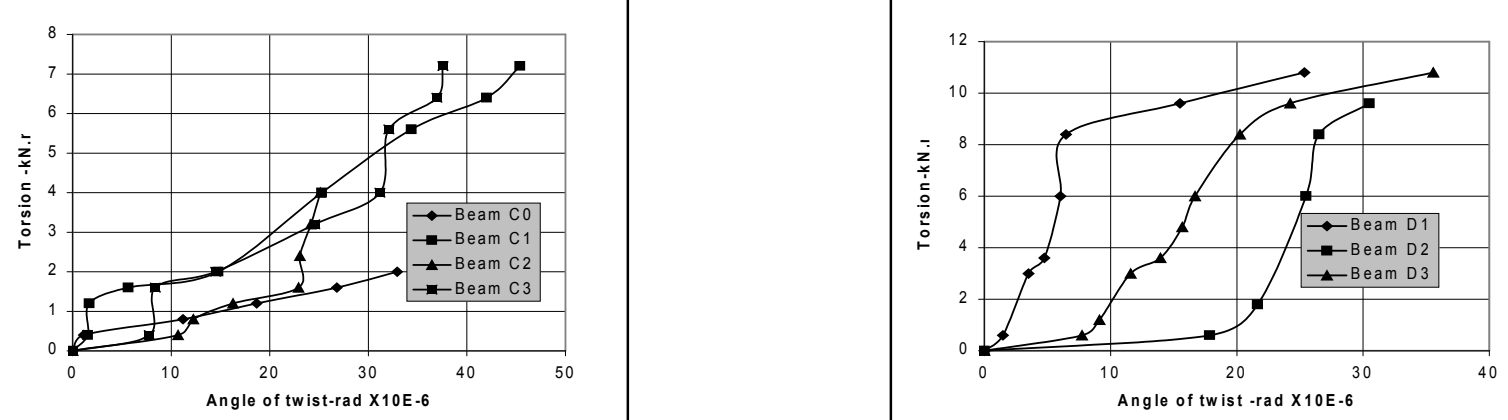


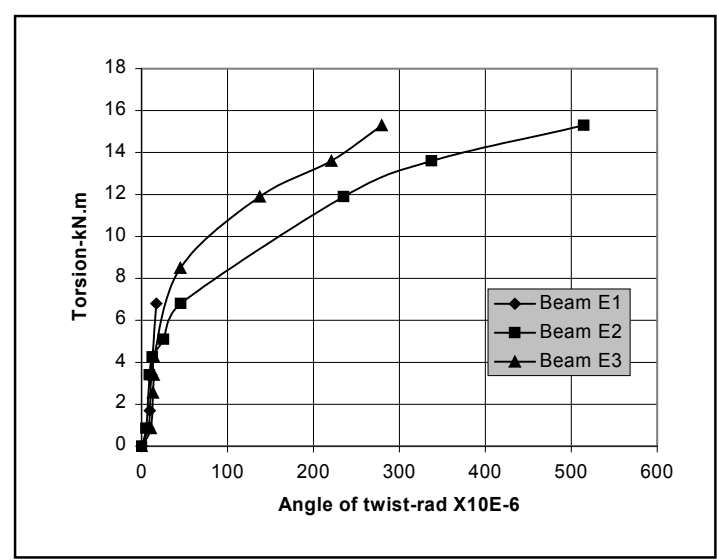

Figure (16) Torsional moment versus angle of twist for beams in group $E$ 


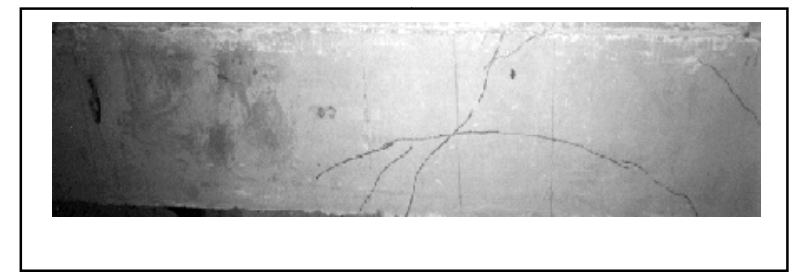

Top view for beam C-0

C-0

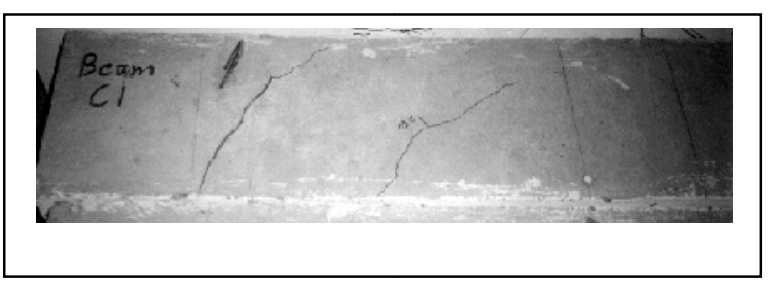

Top view for beam C-I

for beam C-I

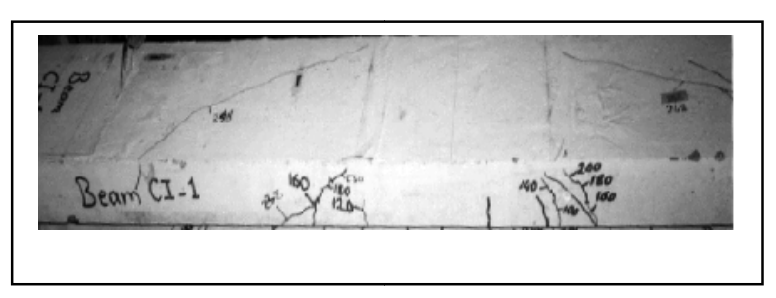

Side view for beam

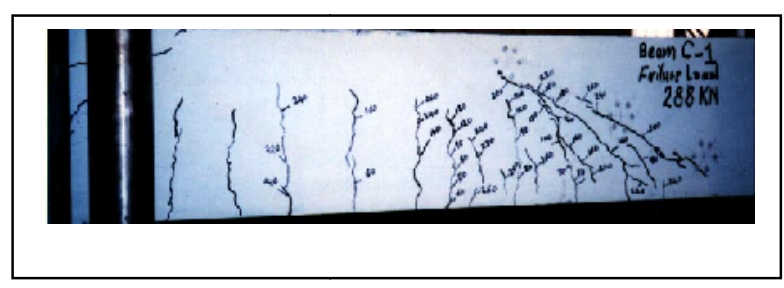

Side view

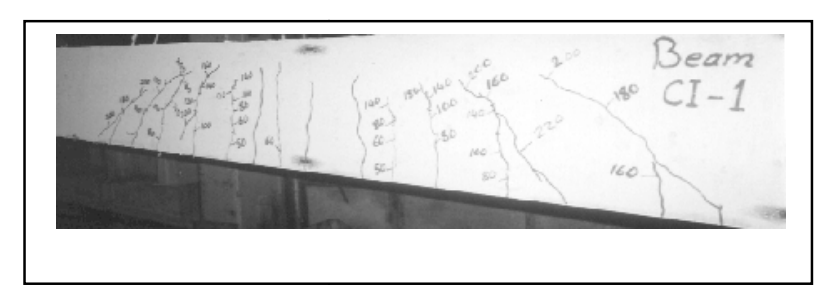


Top view for beam C-I-1

Side view for beam

C-I-1

Figure (17) Continue
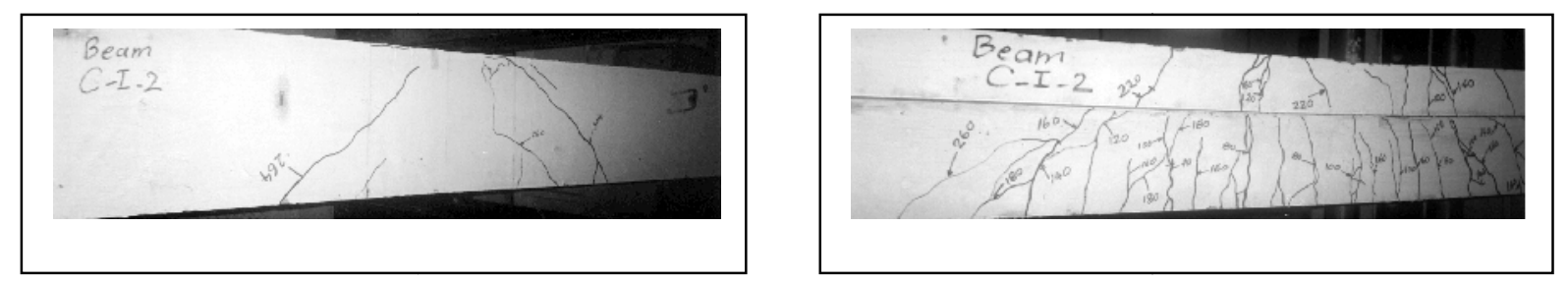

Top view for beam C-I-2

Side view for

beam C-I-2
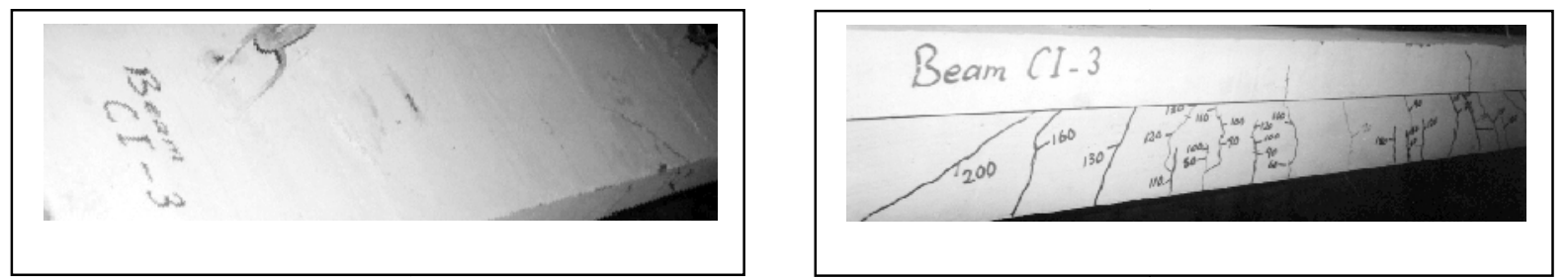

Top view for beam C-I-3

beam C-I-3
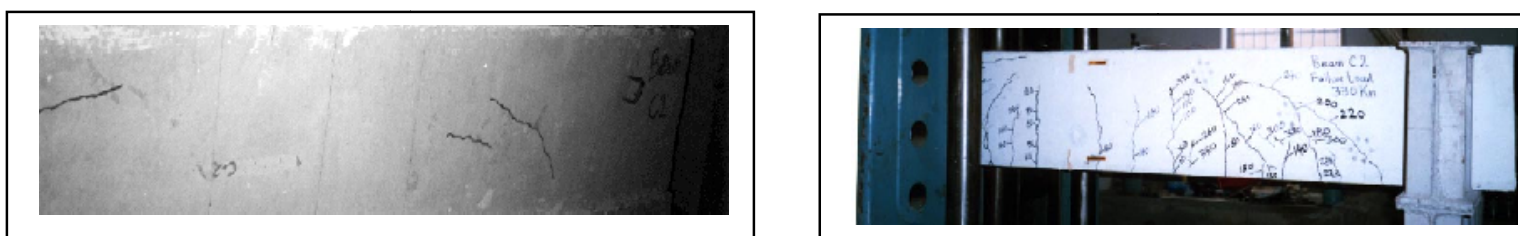
Top view for beam C-2

beam C-2

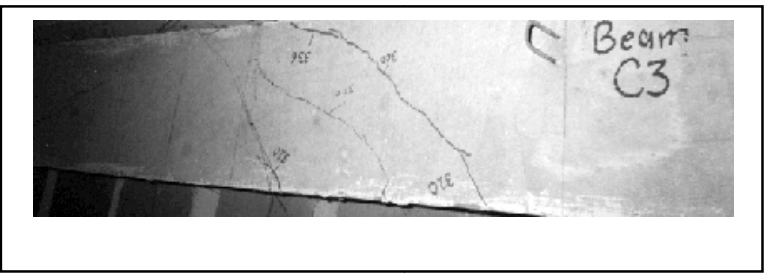

Top view for beam C-3

beam C-3

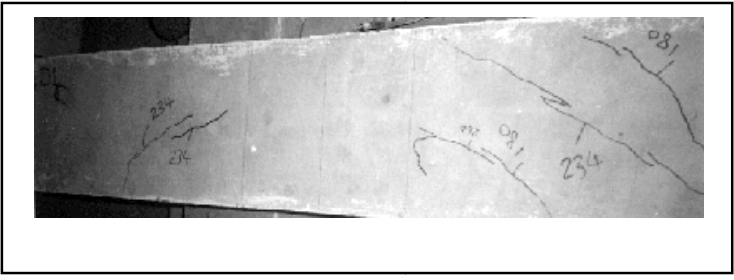

Top view for beam D-1

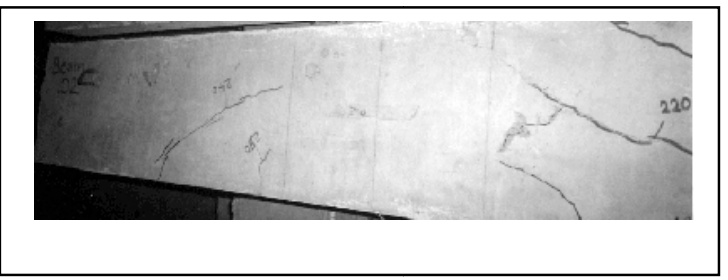

Side view for

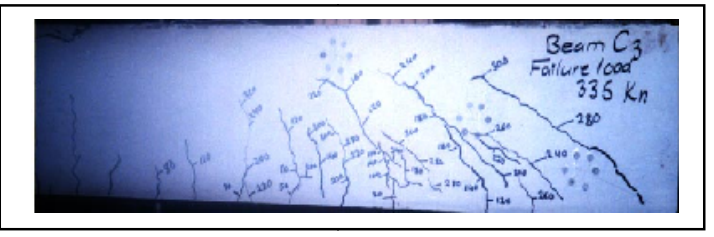

Side view for

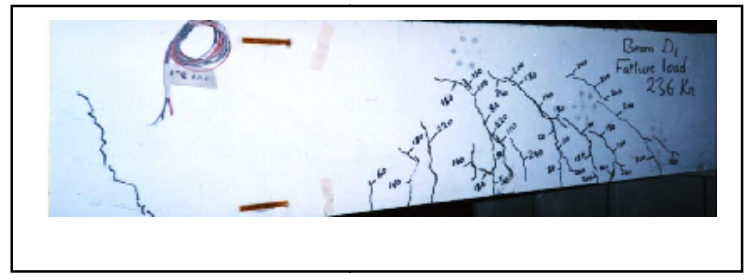

Side view for beam D-1

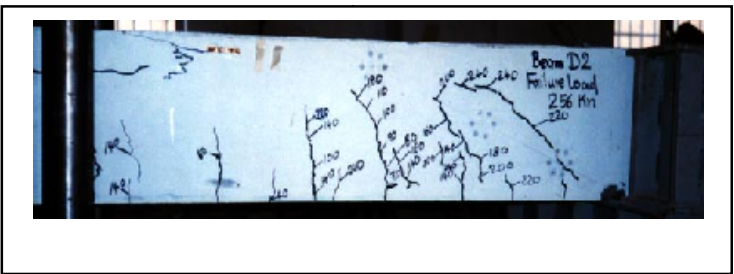


Top view for beam D-2

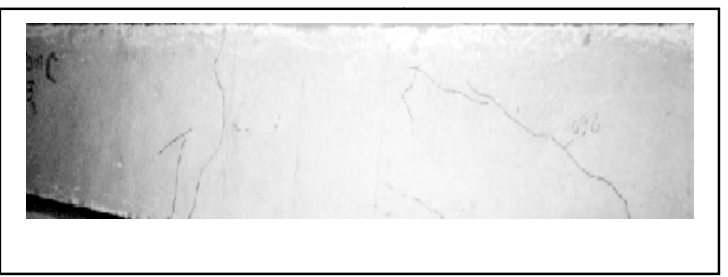

Top view for beam D-3

beam D-3

\section{beam D-3}

Side view for beam D-2

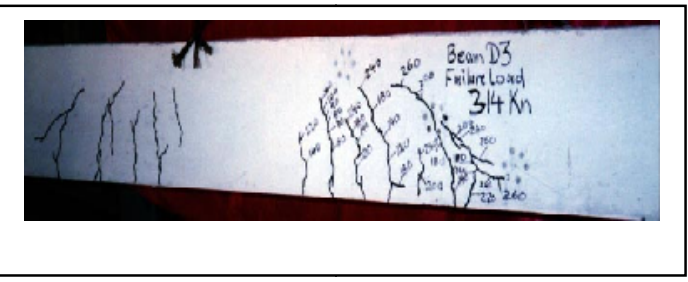

Figure (17) Continue

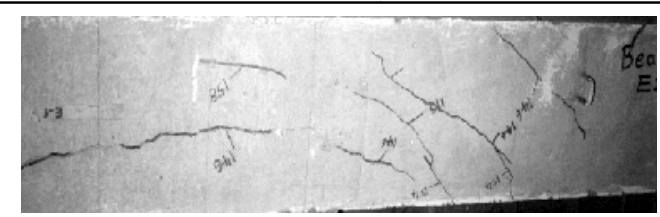

Side view for

Top view for beam E-1

Side view for

beam E-1
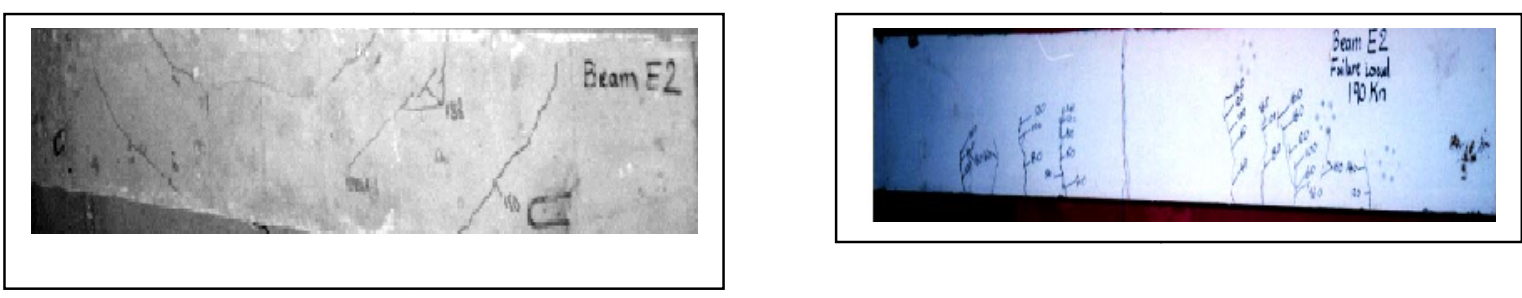


\section{beam E-2}

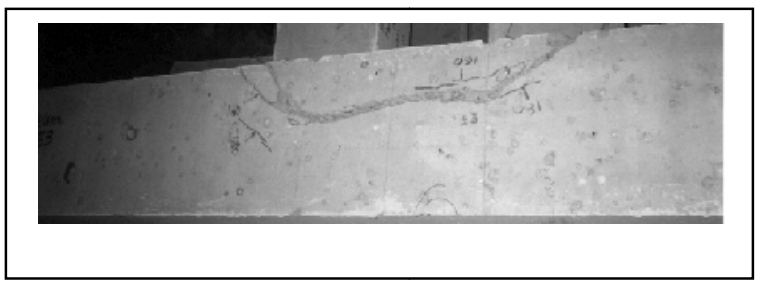

Top view for beam $\mathrm{E}-3$

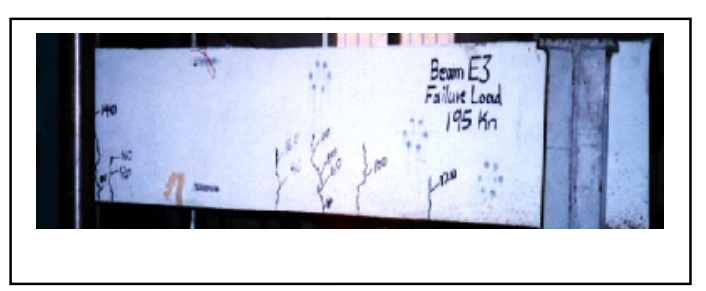

Side view for beam E-3

Figure (17) Crack patterns for beams

\section{Statistical Analysis:}

\section{Cracking shear strength:}

Thirteen beams are taken in this work and used to predict the equation of cracking shear strength of beams under bending, shear and torsion. The equations attained by multiple stepwise regression method, and the best proposed equation can be written as follows:

$$
V_{c r}=\frac{69.708}{\left(f_{c} \cdot b_{w} \cdot d\right)^{0.000256}}
$$

\section{Torsional cracking moment:}

In addition to [13] beams in this work, [16] beams in other literature ${ }^{(19)}$ are taken to predict cracking torque, for this purpose Multiple nonlinear stepwise regression is used, and the best proposed equation can be written as follows: 


$$
T_{c r}=2.14\left(\frac{C \cdot A_{b} \cdot d_{a} \cdot L / d}{d / b_{w}}\right)
$$

This equation has clearly shown the effect of concrete compressive strength on the cracking torque.

\section{Ultimate torsional moment:}

Multiple nonlinear stepwise regression method is used to predict equation for determining ultimate torque. In addition to [13] beams from this work and [16] beams in the other literatures ${ }^{(20)}$, and the most practical equation can be written as follows:

$T_{u}=12.4413\left(\frac{\frac{d_{a}}{d_{b}} \cdot C}{\rho_{w T}}\right)^{0.006660}$

Where:

$\mathrm{d}_{\mathrm{a}}$ : Maximum size of coarse aggregate, $\mathrm{mm}$.

$\mathrm{d}_{\mathrm{b}}$ : Maximum diameter of longitudinal bar, $\mathrm{mm}$

C: Concrete cover, mm.

$\rho_{w T}$ : Longitudinal reinforcement for bending and torsion, $\%$.

\section{Comparison between the proposed equations with codes of practice:}

The equations proposed are tested and compared with other proposed equations in the codes of practice. For all the proposed equations the relative value of experimental to predicted value were found then standard deviation, standard error, coefficient of variation and coefficient of determination were also calculated for each equation. These proposed equations are limited to compressive strength ranging between 
[21 to 83] $\mathrm{MPa}$ for beams under bending, shear and torsion with shear span to effective depth ratio ranging between $\left[\begin{array}{ll}2.5 \text { to } 6 & \text { ]. }\end{array}\right.$

MSC and HSC beams under bending, shear and torsion:

Cracking shear strength:

The cracking shear strength calculated by proposed equation (8) and equations given by codes of practice are listed in Table (4). The ACI-code, BS and proposed have good correlation, ACI code and proposed equation have lower COV than others and BS and proposed equation have values of AVG near unity.

Table (4) Comparing cracking shear strength for MSC \& HSC beams under bending, shear and torsion by various proposed equations

\begin{tabular}{|l|l|l|l|l|l|}
\hline Pro. equation & $\mathrm{R}^{2}$ & $\mathrm{SD}$ & $\mathrm{SE}$ & $\mathrm{COV}-\%$ & $\mathrm{AVG}$ \\
\hline ACI-code & 0.9619 & 3.887 & 14.886 & 1.5595 & 1.1934 \\
\hline BS-code & 0.9337 & 6.982 & 22.394 & 2.8014 & 1.0605 \\
\hline $\begin{array}{l}\text { Canadian } \\
\text { code }\end{array}$ & 0.8727 & 8.5997 & 28.086 & 3.4502 & 1.3812 \\
\hline Eq.(8) & 0.9357 & 5.9406 & 19.402 & 1.9861 & 1.0358 \\
\hline
\end{tabular}

\section{Cracking torque:}

The cracking torque calculated by the proposed equation (9) and the equations given by some codes of practice are listed in Table (5). The proposed equation has lower values of SD, SE,COV and AVG than other codes of practice.

Table (5) Comparing cracking torque for MSC and HSC beams under bending, shear and torsion by various proposed equations

\begin{tabular}{|l|l|l|l|l|l|}
\hline Pro. equation & $\mathrm{R}^{2}$ & $\mathrm{SD}$ & $\mathrm{SE}$ & COV-\% & AVG \\
\hline ACI-code & 0.9579 & 0.3121 & 1.6184 & 13.958 & 1.5145 \\
\hline Canadian & 0.9453 & 0.3066 & 1.5897 & 17.796 & 1.9937 \\
\hline
\end{tabular}




\begin{tabular}{|l|l|l|l|l|l|}
\hline code & & & & & \\
\hline Eq.(9) & 0.9778 & 0.2416 & 1.2547 & 0.5270 & 1.0449 \\
\hline
\end{tabular}

\section{Ultimate torsional moment:}

The ultimate torque calculated by equations given by codes of practice are compared with the proposed equation (10) and listed in Table (6). The proposed equation has good correlation, ACI and Canadian code have the same values of COV and lower than BS and proposed equation. Proposed equation has values of AVG lower than the others.

Table (6) Comparing ultimate torque for MSC and HSC beams under bending, shear and torsion by various proposed equations

\begin{tabular}{|l|l|l|l|l|l|}
\hline $\begin{array}{l}\text { Proposed } \\
\text { equation }\end{array}$ & $\mathrm{R}^{2}$ & $\mathrm{SD}$ & $\mathrm{SE}$ & $\mathrm{COV} \%$ & $\mathrm{AVG}$ \\
\hline ACI-code & 0.6204 & 1.6997 & 8.7963 & 12.558 & 1.6939 \\
\hline BS-code & --- & 1.6003 & 8.2802 & 21.8830 & 2.3470 \\
\hline $\begin{array}{l}\text { Canadian } \\
\text { code }\end{array}$ & 0.6204 & 1.6997 & 8.7963 & 12.558 & 1.6939 \\
\hline Eq.(10) & 0.9271 & 0.6878 & 3.5717 & 19.263 & 1.1195 \\
\hline
\end{tabular}

\section{Conclusions:}

The following conclusions can be stated:

1. An increase in the eccentricity of loading on beam by $112.5 \%$ causes a decrease in ultimate resisting torsional moment by $(15.44 \%)$.

2. An increase in torsional longitudinal reinforcement by $90.29 \%$ causes an increase in load carry capacity by (7.34\%).

3. An increase in torsional transverse reinforcement by $66.34 \%$ causes an increase in shear strength at ultimate load by $27.3 \%$.

4. If the applied torque is increased, the deflection at failure is reduced. 
5. The proposed equations show good agreement when compared with the equations given by codes of practice such as (ACI, Canadian, and $\mathrm{BS})$.

\section{References:}

1. ACI Committee 363 "State-of-the-Art Report on High-Strength Concrete," (ACI 363R-92), American Concrete Institute,Detroit, 1992, 59 pp.

2. Wang, C.K. and Salmon, C.G. "Reinforced Concrete Design," Library of congress cataloging in publication data, 4th edition, 1984,pp.739789.

3. Rasmussen, L.J. and Baker, G. "Torsion in Reinforced Normal and High Strength Concrete Beams -Part 1: Experimental test series,"ACI Structural Journal, V.92, Jan.-Fer., 1995, pp.56-62.

4. Rasmussen, L.J. and Baker, G. "Torsion in Reinforced Normal and High strength concrete Beams-Part2: Theory and Design," ACI Structural Journal, V.92, March-April, 1995, pp.149-156.

5. Collins, M.P. and Mitchell,D., “ Shear and torsion design of prestressed and Non-prestressed concrete beams, " ACI Journal, V.25,No.5, Sep.-Oct.,1980, pp.32-100.

6. Koutchoukali, N.E. \& Belarbi, A. "Torsion of High Strength Reinforced Concrete Beams and Minimum Reinforcement Requirement, "ACI Structural Journal, V.98, No.4, July, 2001.

7. ACI Committee 318, "Building Code Requirements for Reinforced Concrete (ACI-318-99)," American Concrete Institute,Detroid, 1999.

8. Zararis, P.D. and Penelis, G.Gr. "Reinforced Concrete T-beams in Torsion and Bending, "ACI Journal, V.83, Jan.-Fer., 1986, pp.145154.

9. Leung, M.B. and Schnobrich, W.C. "Reinforced Concrete Beams Subjected to Bending and Torsion," Journal of Structural Engineering, V.113, No.2, Feb., 1987, pp.307-321. 
10. Ahmad, S.H. and Lue, D.M. "Flexure-Shear interaction of Reinforced High Strength Concrete Beams," ACI Structural Journal, V.84, JulyAugust, 1987, pp.330-341.

11. Roller, J.J. and Russell, H.G. "Shear Strength of High Strength Concrete Beams with Web Reinforcement," ACI Structural Journal, Vol.87, March-April, 1990, pp.191-198.

12. Rahal, K.N. and Collins, M.P. "Analysis of Sections Subjected to Combined Shear and Torsion--A theoretical model," ACI Structural Journal, V.92, No.4, July 1995.

13. Rajagopalan, K.S. "Combined Torsion, Bending and Shear on LBeams," Journal of the structural division, V.106, No.ST12, Dec., 1980, pp.2475-2492.

14. Aziz O.Q. "Effect of Revibration time and high temperature on the High Strength Fibrous Concrete properties,"JDU (sei), V.2, No.5, April, 1999, pp.693-701.

15. Buni, Z.K. "Effect of Shear Span to Depth ratio on Shear Strength for HSC Beams, "M.Sc, Thesis, Univ. of Technology, Dec., 1994.

16. An American National Standard, "Slump of Portland Cement Concrete," ASTM C143,American Association State, 1978.

17. An American National Standard, "Compressive Strength of Cylindrical Concrete specimens," ASTM C39, American Association State, 1981,PP.25-28.

18. An American National Standard, "Standard Test Method for Splitting Tensile Strength of Cylindrical Concrete Specimens," ASTM C496, American Association State, 1996.

19. An American National Standard, "Standard Test Method for Static Modulus of Elasticity and Poisson's ratio of Concrete in Compression," ASTM C469, American Association State, 1994.

20. Barton, T.G. and Kirk, D.W. "T-beams subject to Combined Loading," Journal of the structural division, V.99, No.ST4, April, 1973, pp.687-700. 
